\title{
Platelet Characterization in Helicobacter Pylori Patients
}

\author{
Sahwa Ahmed Ali, Nasr Eldeen Ali Mohammed Gaufri* \\ Department of Haematology, Faculty of Medical Laboratory Sciences, Alneelain University, Khartoum, Sudan \\ Email: *Nasralimohammed@yahoo.com
}

How to cite this paper: Ali, S.A. and Gaufri, N.E.A.M. (2017) Platelet Characterization in Helicobacter Pylori Patients. Open Access Library Journal, 4: e3637. https://doi.org/10.4236/oalib.1103637

Received: April 26, 2017

Accepted: August 8, 2017

Published: August 11, 2017

Copyright ( 2017 by authors and Open Access Library Inc.

This work is licensed under the Creative Commons Attribution International License (CC BY 4.0).

http://creativecommons.org/licenses/by/4.0/

\begin{abstract}
Background: Recently the data has been increasing on the association between Helicobacter pylori infection and thrombocytopenia characterization specifically in developing countries. Objective: This study was aimed to evaluate platelet count and platelet indices in Helicobacter pylori infected patients. Materials and Method: This is a case control study conducted in the Faculty of Medical Laboratory at Alneelain University, Khartoum-Sudan. A total of 240 participants was enrolled in this study; 120 of them are a patient group known diagnosed with $H$. pylori infection; 60 (50\%) male, 60 (50\%) female; their mean age is $(30.22 \pm 1.92)$ years designed as patient group. And another 120 designated as normal, healthy control group; 60 (50\%) male and 60 (50\%) female. Blood samples were collected from each subject in ethylene diamine tetra acetic acid (EDTA). The platelet count and platelet Indices were done by using full automated hematological Analyzer Sysmex (KXN-21) Japan. The data were analysed by using (SPSS) version 20. Result: Platelet count and platelet distribution width (PDW) were shown statistically significantly lower; on the other hand the MPV was found higher in patients with $H$. pylori infection compared with normal healthy control group with $\mathrm{p}$ value $0.03,0.01$ and 0.00 respectively. Conclusion: Mild thrombocytopenia with elevated in mean platelet volume (MPV) and low on the platelet distribution width (PDW) were found in patients with $H$. pylori infection.
\end{abstract}

\section{Subject Areas}

Hematology

\section{Keywords}

Helicobacter pylori, Platelet Count, Platelet Distribution Width, Mean Platelet Volume, Sudan 


\section{Introduction}

Helicobacter pylori, a spiral shaped pathogenic bacterium found in the human gastric mucosa, was first isolated by Warren and Marshall in 1982 and soon after was linked with chronic gastritis and peptic ulceration [1]. It is a common bacterial infection worldwide with the prevalence's ranging from $30 \%$ to $90 \%$ [2], The annual incidence rate of Helicobacter pylori is $4 \%-15 \%$ in developing countries, compared with $0.5 \%$ in industrialized countries [3]. It is Gram negative microaerophilic bacterium that can inhabit various areas of the stomach, particularly the antrum [1]. H. pylori colonize the human stomach and trigger gastric inflammation; it promotes many of proinflammatory cytokines which cause gastric mucosa damage. Although high prevalence of infection, small proportion of population suffer from the gastro-duodonal disease associated with $H$. pylori infection [4]; clinical features of this infection are: Abdominal pain, classically epigastric with severity relating to mealtimes, after around three hours of taking meal (duodenal ulcers are classically relieved by food, while gastric ulcers are exacerbated by it), bloating and abdominal fullness, water brash (rush of saliva after an episode of regurgitation to dilute the acid in esophagus), nausea and copious vomiting, loss of appetite and weight loss, hematemesis (vomiting of blood), Melena (tarry, foul-smelling feces due to oxidized iron from hemoglobin) and rarely, an ulcer can lead to gastric or duodenal perforation, which leads to acute peritonitis [4]. Infection by $H$. pylori if doesn't eradicate can lead to some complications such as Gastrointestinal bleeding, Perforation a hole in the wall often leads to catastrophic consequences, ulcer and Cancer [5]. Also infected by $H$. pylori is frequent cause of iron refractory or iron dependent anemia [6]. Platelets are intimately involved in homeostasis, inflammation, immunity and tissue regeneration and other physiological and pathological processes [7]. Platelet play an important role in the pathogenesis of disorders associated with local or systemic inflammation [8], thrombotic and inflammatory agents is released from platelets may cause complication [9]. The mean platelet volume (MPV) is marker of platelet function and activation, large platelet are hemostaticlly more active.MPV has long been recognized as an inflammatory marker and its role has been previously demonstrated in various gastrointestinal [6]. Platelet distribution width (PDW) reflects how the platelets are in size [10].

\section{Materials and Method}

This is case control study was conducted in the Faculty of Medical Laboratory Science, Alnaleein University and during August 2015. A total of 240 participates were enrolled in this study, 120 patients known diagnosed with $H$. pylori infection using urea breath test (UBT); 60 (50\%) were male and 60 (50\%) were female; their mean age is $(30.22 \pm 1.92)$ years designed as patient group, for the patient diagnosed the biopsy of gastric antrum was collected, during upper gastrointestinal endoscopy under aseptic condition in sterile cup containing $1 \mathrm{ml}$ of sterile saline for Gimsa stain. H. pylori was diagnosed according positive 
staining with Gimsa (curved-shaped). During the endoscopic examination, patients were evaluated for the presence of gastritis, peptic ulcer and erosion. Further 120 normal, healthy subjects designed as a control group; their age and gender matched with patient group. Patients who recently received blood transfusions, or under treatment with aspirin, or any antibiotic, smoking, pregnant and lactating females and patients with a history of alcohol abuse were excluded from this study. Our study was approved by the scientific research committee of the faculty of medical laboratory sciences, Alneelain University, and the informed consent was taken from all participants in this study before the samples collected. Three milliter of venous blood samples were collected from every volunteer in container contains EDTA as an anticoagulant, then the platelet count and platelet indices were immediately done using full automated hematological Analyzer Sysmex (KXN-21) Japan. The data were analysed by using statistical package for the social sciences (SPSS) version 20. The T. test was used for comparison between different study groups, $\mathrm{P}$ value less than 0.05 was considered significant.

\section{Result}

The present study showed that the platelet count was statistically significantly lower in patients with $H$. pylori infection compared with those normal control groups with (P value 0.03 ) Table 1 .

The current study found that the MPV was statistically significantly higher in patients with $H$. pylori infection compared with normal healthy control groups (P value 0.00 ) Table 1.

The platelet distribution width in our study was statistically significantly lower in patients with $H$. pylori infection compared with normal healthy control group (P value 0.01 ) Table 1.

\section{Discussion}

Helicobacter pylori Infection rates are strongly related to poor living conditions and overcrowding during childhood, cross-sectional survey show that there is steady rise in seropositivity with increasing age [11]. When $H$. pylori enters the body, it attacks the lining of stomach, which usually protects the body from the

Table 1. Correlation of platelet count \& platelet indices in patients with $H$. pylori infection and normal, healthy control groups.

\begin{tabular}{ccccc}
\hline Variable & Subjects number & $\begin{array}{c}\text { Patients group } \\
\text { Mean } \pm \text { SD }\end{array}$ & $\begin{array}{c}\text { Controls group } \\
\text { Mean } \pm \text { SD }\end{array}$ & P value \\
\hline PLT count & 120 & $138.44 \pm 46.34$ & $211.4 \pm 48.6$ & 0.03 \\
MPV & 120 & $13.7 \pm 2.1$ & $8.27 \pm .1 .8$ & 0.00 \\
PDW & 120 & $9.30 \pm .91$ & $11.36 \pm 1.08$ & 0.01 \\
\hline
\end{tabular}

Abbreviation PLT: platelet PDW: platelet distribution width MPV: Mean platelet volume; P value less 0.05 was considered significant. 
acid which uses to digest food, once the bacteria have done enough damage, acid can get through the lining which lead to ulcer and cause bleeding [12]. Aziz Mirghani et al., report that, the prevalence of $H$. pylori infection in Sudanese patient with gastro-duodenal inflammation was $80 \%$ [13], the second study was reported that there is high prevalence of $H$. pylori among Sudanese pregnant women [14]. Several epidemiological studies have shown a relationship between chronic $H$. pylori infection and coronary artery disease [15] [16]. one study report that eradication of $H$. pylori can improve endothelial dysfunction [17]. Some Studies report that eradication of $H$. pylori improves thrombocytopenia in some patients with immune thrombocytopenia purpura by mechanisms that remainobscure [18] [19]. MPV was assessment in different disorder, in myocardialinfarction was found high [20] while was showed decreased in Rheumatoid arthritis and inflammatory bowel disease [21]. This study aimed to assess platelet count, MPV and PDW in Sudanese patients with $H$. pylori infection. The present study revealed that, the platelet count was decreased in patients with $H$. pylori infection in comparing with normal non infected, this finding in agreement with study report that autoimmunity may play a part in determining gastric mucosal damage caused by $H$. pylori [22]. Our finding also in the same line with another study that report $H$. pylori infection induced in platelets count [23]. Our interesting finding was inconsistent with Matsukawa $Y$ in (2011) who reported in Act a Haematolgica the $H$. pylori Japanese infected women were showing higher platelet counts in comparison with non $H$. pylori infected women, while Sudanese female showed decreased platelet counts comparing with normal control women this may be attributed to ethnic background [24]. The present study showed that the MPV level was statistically significantly higher in patients with $H$. pylori infection compared with normal healthy control groups. This findings in consent with studies (2010) done in Turkey [25] and with study cited by Abdullah Ozgur et al who reported that $H$. pylori infection can cause aggregation (thrombocytopenia)and activation high MPV [26]. Our findings in contrast with study in Turkey (2010)by Topal F et al who reported that there is nostatistically significant different in MPV between helicobacter pylori infected patients and normal healthy subjects, this might be assign to ethnic and different population [27]. The platelet distribution width in our study was statistically significantly lower in patients with $H$. pylori infection in comparison with normal non $H$. pylori infected group. The major limitations in the present study are the small sample size, and relatively short study period.

\section{Conclusion}

The present study concluded that Sudanese patients with H. pylori infection had mild thrombocytopenia with elevated in MPV levels.

\section{References}

[1] Marshall, B.J., Warren, J.R. (1984) Unidentified Curved Bacilli in the Stomach of Patient with Gastritis and Peptic Ulceration. Lancet, 1, 1311-1315. 
[2] Goodwin, C.S., Armstrong, J.A., Chilvers, T., Peters, M., Collins, M.D., Sly, L., MacConnell, W. and Harper, W.E.S. (1989) Transfer of Campylobacter pylori and Campylobacter Mustelae to Helicobacter gen. nov. as Helicobacter pylori comb. nov. and Helicobacter mustelae comb. nov., Respectively. Int. J. Syst. Bacteriol., 39, 397-405.

[3] Kate, V., Ananthakrishnan, N. and Tovey, F.I. (2013) Is Helicobacter pylori Infection the Primary Cause of Duodenal Ulceration or a Secondary Factor? A Review of the Evidence. Gastroenterology Research and Practice, 2013, Article ID: 425840.

[4] Amieva, M.R. and EL-Omer, E.M. (2007) Host Bacterial Interaction in helicobacter pylori infection. Journal of Gastroenterology, 134, 306-323.

[5] Smoot, D.T. (1997) How Does Helicobacter Pylori Cause Mucosal Damage? Direct Mechanisms. Gastroenterology, 113, S31-S34.

[6] Monzón, H., Forne, M., Rosinach, M., Loras, C., et al. (2013) Helicobacter pylori Infection as a Cause of Iron Deficiency Anaemia of Unknown Origin. World Journal of Gastroenterology, 19, 4166-4171.

[7] Ware, J., Corken, A. and Khetpal, R. (2013) Platelet Function beyond Hemostasis and Thrombosis. Current Opinion in Hematology, 20, 451-456.

[8] Rondina, M.T., Weyrich, A.S. and Zimmerman, G.A. (2013) Platlete as Celluler Effectors of Inflammation in Vascular Disease. Circulation Research, 112, 1506-1519.

[9] Jenne, C.N., Urrutia, R. and Kubes, P. (2013) Platelet: Bridging Hemostasis, Inflammation and Immunity. International Journal of Laboratory Hematology, 35, 254-261.

[10] Lui, S., Ren, J., Han, G., et al. (2012) Mean Platelet Volume: A Controversial Marker of Disease Activity in Crohn's Disease. European Journal of Medical Research, 17, 27.

[11] Smith, S.M., O’Morain, C. and McNamara, D. (2014) Antimicrobial Susceptibility Testing for Helicobacter pylori in Times of Increasing Antibiotic Resistance. World Journal of Gastroenterology, 20, 9912-9912.

[12] Weston, A.P., Badr, A.S., Topalovski, M., Cherian, R., Dixon, A. and Hassanein, R.S. (2000) Prospective Evaluation of the Prevalence of Gastric Helicobacter pylori Infection in Patients with GERD, Barrett's Esophagus, Barrett's Dysplasia, and Barrett's Adenocarcinoma. The American Journal of Gastroenterology, 95, 387-394. https://doi.org/10.1111/j.1572-0241.2000.01758.x

[13] Azim Mirghani, Y.A., Ahmed, S., Ahmed, M., Ismail, M.O., Fedail, S.S., Kamel, M. and Saidia, H. (1994) Detection of Helicobacter pylori in Endoscopic Biopsies in Sudan. Tropical Doctor, 24, 161-163. https://doi.org/10.1177/004947559402400407

[14] Mubarak, N., Gasim, G.I., Khalafalla, K.E., Ali, N.I. and Adam, I. (2014) Helicobacter pylori, Anemia, Iron Deficiency and Thrombocytopenia among Pregnant Women at Khartoum, Sudan. Transactions of the Royal Society of Tropical Medicine and Hygiene, 108, 380-340. https://doi.org/10.1093/trstmh/tru044

[15] Khulusi, S., Mendall, M.A., Patel, P., Levy, J., Badve, S. and Northfield, T.C. (1995) Helicobacter pylori Infection Density and Gastric Inflammation in Duodenal Ulcer and Non-Ulcer Subjects. Gut, 37, 319-324. https://doi.org/10.1136/gut.37.3.319

[16] Patel, P., Mendall, M.A., Carrington, D., et al. (1998) Association of Helicobacter pylori and Chlamydia pneumoniae Infections with Coronary Heart Disease and Cardiovascular Risk Factors. BMJ, 311, 711-714. https://doi.org/10.1136/bmj.311.7007.711

[17] Blum, A., Tamir, S., Mualem, K., Ben-Shushan, R.S., Keinan-Boker, L. and Paritsky, 
M. (2011) Endothelial Dysfunction Is Reversible in Helicobacter pylori-Positive Subjects. The American Journal of Medicine, 124, 1171-1174. https://doi.org/10.1016/j.amjmed.2011.08.015

[18] Veneri, D., Bonani, A., et al. (2011) Idiopathic Thrombocytopenia and Helicobacter pylori infection: Platelet Count Increase and Early Eradication Therapy. Blood Transfusion, 9, 340-342.

[19] Shaikh, K.H., Ahmed, S., Ayyub, M. and Anwar, J. (2009) Association of Helicobacter pylori Infection with Idiopathic Thrombocytopenic Purpura. Journal of the Pakistan Medical Association, 59, 660-663.

[20] Öztürk, Z.A., et al. (2013) Could Platelet Indices Be New Biomarkers for Inflammatory Bowel Diseases? European Review for Medical and Pharmacological Sciences, 17, 334-341.

[21] Kapsoritakis, A.N., et al. (2001) Mean Platelet Volume: A Useful Marker of Inflammatory Bowel Disease Activity. The American Journal of Gastroenterology, 96, 776-781. https://doi.org/10.1111/j.1572-0241.2001.03621.x

[22] Bergman, M.P., Faller, G., D’Elios, M.M., et al. (2001) Gastric Autoimmunity. In: Mobley, H.L.T., Mendz, G.L. and Hazell, S.L., Eds., Helicobacter pylori: Physiology and Genetics, Chap. 36, ASM Press, Washington DC, 429-440.

https://doi.org/10.1128/9781555818005.ch36

[23] Hasni, S.A. (2012) Role of Helicobacter pylori Infection in Autoimmune Diseases. Current Opinion in Rheumatology, 24, 429-434.

https://doi.org/10.1097/BOR.0b013e3283542d0b

[24] Matsukawa, Y., Kitamura, N., et al. (2011) Helicobacter pylori Upregulates Peripheral Platelet Counts Mainly in Female Patients. Acta Haematologica, 126, 172175. https://doi.org/10.1159/000329011

[25] Umit, H. and Umit, E.G. (2015) Helicobacter pylori and Mean Platelet Volume: A Relation Way before Immune Thrombocytopenia? European Review for Medical and Pharmacological Sciences, 19, 2818-2823.

[26] Yeniova, A.O., Kucukazman, M., et al. (2013) Investigation of the Association between Mean Platelet Volume and Helicobacter pylori Gastritis. African Journal of Microbiology Research, 7, 2179-2183. https://doi.org/10.5897/AJMR2013.2520

[27] Firdevs, T., Kerem, K., et al. (2010) The Relationship between Mean Platelet Volume Levels and the Inflammation in Helicobacter pylori Gastritis. Journal of the National Medical Association, 102, 726-730. 
Submit or recommend next manuscript to OALib Journal and we will provide best service for you:

- Publication frequency: Monthly

- 9 subject areas of science, technology and medicine

- Fair and rigorous peer-review system

- Fast publication process

- Article promotion in various social networking sites (LinkedIn, Facebook, Twitter, etc.)

- Maximum dissemination of your research work

Submit Your Paper Online: Click Here to Submit

Or Contact service@oalib.com 